\title{
Spain's contribution to the advancement and consolidation of the European political union
}

\author{
Francisco ALDECOA LUZARRAGA*
}

\begin{abstract}
The purpose of this article is to analyse Spain's contribution to the advancement and consolidation of the European political union on the occasion of the thirtieth anniversary of Spain joining the European Community. The article describes profound transformations that the European Community underwent in the process of transforming into the European Union showing that Spain has been part of the group of countries that led these transformations becoming a country that belongs to the core of the European Union with a status similar to that of the six founding countries.
\end{abstract}

\section{GENERAL CONSIDERATIONS}

Many articles have been written about the European Community/European Union's contribution to the consolidation of Spain's democracy and prosperity. This work deals with the commemoration of the zoth anniversary of Spain joining the EC-EU from the opposite perspective, that is to say, what Spain has contributed to the European Union, particularly from the political dimension. It will thus answer the following questions: Have Spain, its government, and its people significantly contributed to the building of Europe and especially to the political union's consolidation? If the answer is yes, what is this contribution and how can it be explained? What are the factors behind it? In turn, we will reflect on how this contribution fits into the debate about the future of Europe.

There is no doubt in this author's mind that the European Union's political model today, in the middle of the second decade of the 2ist century, is qualitatively different from that of the European Community of the I980s. In fact, there are more differences than similarities between the European Union and the European Community.

We will analyse how Spain, which was absent in the first phase of the building of Europe, has played a central role in transforming an economic community into a political union. As a result of its being a loyal and effective partner - despite a certain retreat the last five years due to the economic crisis - it belongs nowadays at the core of European integration.

With this article we take the first step toward studying Spain's contribution to the last 30 years of European construction, remaining aware that we are leaving out much. We only attempt to highlight what are to our mind the most relevant trends and elements in Spain's contribution to the European political model, thinking above all about the future. To this end we will provide some examples, though there are many others we hope to analyse another time.

* Professor of International Relations, Complutense University of Madrid. Vice-president of the Spanish Federal Council of the European Movement. This article is the English version of his contribution to E. Nasarre \& F. Aldecoa (coord.), Treinta años de España en la Unión Europea. El camino de un proyecto bistórico (Madrid, Marcail Pons, 2016). 


\section{THE BEGINNING OF A HISTORIC PROJECT'S TRAJECTORY}

In order to understand the Spanish paradox we must return to the birth of the European communities. The "paradox" is that Spain, despite not having been a formal participant in the birth and development of the European Community - since it was not party to the 195I Treaty of Paris or the 1957 Treaty of Rome due to the political mortgage implied by Franco's regime- would nevertheless become a state with a central role in the European Community's political transformation and in the European political union's development.

Already at the Congress of Europe in The Hague in 1948, in which the main protagonists of the building of Europe - those later called the "founding fathers of Europe" - participated, is where the European project began to be forged. Spanish political leaders of the exiled opposition, including the liberal Salvador de Madariaga, the Christian Democrat Jose Antonio Aguirre, and the Socialist Indalecio Prieto, took part in this Congress. They were of differing political views and were affiliated with political forces that would soon constitute the engine of Europe.

It was obviously impossible for the forces that sustained Franco's regime to be represented, but there were democratic political parties that represented Spanish society and the aspiration and desire to form part of this historic project that brought together and tried to overcome the confrontation of world wars and our civil war.

The presence of this opposition remained active in Europe until the political transition and Europe was even a meeting place for Spaniards, as shown by the apt words pronounced by Salvador de Madariaga at the so-called "Munich Conspiracy" of 1962, referencing the meeting of Spaniards who had fled, achieving "freedom losing home and those who chose home, losing freedom." Thus begins the collaboration between internal and external democratic opposition, which, according to some authors made the democratic transition 15 years later possible.

On the other hand, this same year, the 9th of February 1962, a famous letter was sent by the Foreign Affairs minister, Fernando Maria Castiella and became Spain's first application for accession to the European Community. In the letter there was a request for "an association eligible to become one day full integration, after passing through the necessary stages that would allow the Spanish economy to align with the conditions of the common market." However, Franco's regime made it impossible for the European institutions to accept this proposal. They did not even answer since Spain did not meet the minimum requirement of being a democracy.

As a consequence of the transition, it became possible that during the second government of Adolfo Suarez, the minister of Foreign Affairs Marcelino Oreja sent a second letter of request for accession - in July 1977- that laid the beginning for negotiations for accession one year later, once the constitution of 1978 was passed. 
After long and difficult negotiations, the Accession Treaty was signed in Lisbon and Madrid on I2 June, 1986, a tragic day due to ETA attacks. The Treaty entered into force on I January 1986, beginning Spain's participation in the European Community.

From its accession Spain had the status of a medium-large country, behind the four big ones, due to its population (which was the fifth with almost 40 million at the time), its geographical area (the second largest), and its Gross Domestic Product (the fifth largest, ahead of the Netherlands). There was also the relevancy of language - Spanish, the third in the world- and a culture and global historical projection, with great influence on its former colonies.

Spain is one of the four important colonial powers and contributes its historical projection in Latin America, its role in the Mediterranean and even, to some extent, its presence in Africa. Moreover, the Iberian Peninsula is at once a bridge between Europe and Africa and between the Mediterranean and the Atlantic, contributing, from the security point of view, an important strategic space.

Of all the enlargements - the process of going from six founding member states to 28 (the current number of members) - Spain's accession is the one that brought the greatest strength to the integration from every point of view, and, overall, the fewest problems. There is no need to remind of the difficulties presented by the United Kingdom, Denmark, and Greece, especially in the different initiatives for changes in the Treaty that implied a deepening of the European construction, not to mention other states that have presented difficulties more recently.

In this way, Spain strengthened the European Community in its dimensions and accepted - not just the government but the whole of Spanish society - the necessity of forming part of the European project, especially its political dimension, always being part of the group that champions more political Europe. It is no coincidence that perhaps the only important treaty that was approved without a single dissenting vote in the Spanish parliament was the Treaty of Accession to the European Community. All of this strengthened European integration.

\section{THE EUROPEAN UNION TODAY: A POLITICAL MODEL QUALITATIVELY DIFFERENT FROM THE EUROPEAN COMMUNITY OF 1985}

Thirty years ago, in the 1980s, when Spain negotiated and signed the Treaty of Accession, the confusing and overlapping debates about Europe and its future were the following:

a) The first one revolved around whether the Community economic model was going to become consolidated and coexist with and influence the other two models: the EFTA countries and the Communist bloc around COMECON;

b) The second revolved around whether the Community political model was going to develop and transform along the path of a European Federation or return back to classic intergovernmental logic;

c) The third one revolved around whether the welfare state that involved public intervention as a form of social regulation in such areas as healthcare, education, and retirement, was going to be the model for European society; 
d) The fourth revolved around whether the Community and the member states could speak with one voice in global affairs - and in its opposition to the Warsaw Pact and the Atlantic Alliancecompatible with the neutrality of four of its members;

e) Finally, it was about distinguishing among these three competing models, which were antagonistic economically, politically and socially, as well as incompatible with regard to the international option, and determining which was going to prevail in the future.

The responses to these debates are pretty clear 30 years later:

a) The Community economic model consolidates in opposition to the alternatives with EFTA reduced to Norway, Switzerland, Iceland and Liechtenstein, becoming, in any case, a group of residual states, with the communist model disappearing altogether.

b) The Community political model of shared sovereignty deepens, transforming into the European Union model of political nature, as opposed to the European Community of economic nature. The European Union today is a union not just of states, but also of states and citizens.

c) The model of society characteristic of the member states gradually becomes adopted by the core of the Union, albeit with different nuances and despite the profound economic crisis of the last six years, which is hopefully just a step back and an aside, and not the disappearance of the model.

d) In relation to foreign policy Europe transforms from the European Political Cooperation of the 1980s, in which there only existed a legal obligation to consult, to a foreign policy with its own diplomacy, compatible with that of the member states - although different - and with the development of the Common Security and Defence Policy (CSDP), forming a defensive alliance distinct from the Atlantic Alliance. One must not forget that the world has changed since 1989, and the end of bipolarity is what in large part allowed Europe to develop its own foreign policy.

e) The model of the Union and the European model tend to align, transforming into a "single Europe" where no group of states that aspires to an alternative model is left out. European states that do not participate in the European Union are candidates, potential candidates, Eastern neighbours or four residual members of EFTA mentioned earlier and which will possibly end up being members (they currently participate in the European Economic Area (EEA) and in a great part of the European Union's foreign policy).

In any case, the model of the Union is only similar to the old Community in the common exercise of the shared sovereign responsibilities, which were solely economic thirty years ago and are now political and social, reaching into all areas: human rights, citizenship, democracy, explicit statement of principles and values, economic and social cohesion, domestic policy, foreign policy, Common Security and Defence Policy, among others. In the end, the Union has a political model distinct from that of the member states, and in turn, from the Community model of the 8os. Spain has played a central role in the achievement of that model, as we shall see below. 
The transformation of the Community into Union begins with the elections to the European Parliament in 1979, which are the first direct elections by universal suffrage. With that begins the first legislature, during which the Draft Treaty establishing the European Union is passed, later called the Spinelli Project, since this federalist was its main promoter. As is well known, it did not enter into force, despite having overwhelming parliamentary support since the governments of the member states believed that it went beyond their interests. Even though Spain was not a member country at the time, from the moment it became such, Spain supported this initiative.

Thus Spain has played a decisive role in five important constitutional reforms. It participated in the Single European Act, which reformed the treaty with a certain political reach, although in that case it participated in the Luxembourg Governmental Conference with the right to speak but not to vote since it was held between the signing of the Treaty in July of 1985 and its entry into force in 1986. It was in the intergovernmental conference where the Treaty of Maastricht was born, which combined to a great extent the elements of the Spinelli Project, among them the very notion of the European Union, citizenship of the Union, democratization of the institutions, foreign policy, single currency, etc. In Maastricht Spain was one of the countries that actively promoted the salvaging of the ideas contained in the parliamentary project, such as as the notion of citizenship, giving it a new impulse.

Spain also participated in the Amsterdam, Nice, and Lisbon reforms, and apart from always being with the group that defended deepening, we contributed themes central to the consolidation of the European political model, such as the abovementioned notion of citizenship, economic and social cohesion, "communitarisation" of the area of freedom, security and justice, fight against terrorism and the euro order, among other constitutional themes, as mentioned by much of the work published on this topic.

However, the relevance of which is generally forgotten, in my opinion, Spain also played a central role in the Constitutional Process, which begins with the European Convention, a role which has great importance, at least through the four following contributions:

a) In the European Convention, with the defence of the need for a constitution carried out by Spanish representatives Diego Lopez Garrido, Carlos Carnero, Josep Borrell and Iñigo Mendez de Vigo. This last one defended in the European Parliament the drafting of the article dealing with the democratization of the Commission, meaning that it would originate as a consequence of elections and today is article 17.7 of the Lisbon Treaty.

b) In the passing of the Constitutional Treaty, at the Dublin Summit in March 2004, with the government of the recently elected Rodriguez Zapatero, unblocking the situation created by the veto of the above mentioned treaty at the Rome Summit in December 2003.

c) With the importance of the Spanish referendum on the Treaty, which established a Constitution for Europe. Thanks to the Spanish votes, the total of the popular vote in favour of the Constitution in the countries that held referendums (Spain, France, Netherlands and Luxembourg) was 26.7 million to 22.5 million against. With that and despite the fact that the "no" vote won in France and the Netherlands, the Constitutional Treaty enjoyed certain popular legitimacy. 
d) Finally, we should highlight the February 2007 Madrid meeting of the foreign ministers of the 18 countries that had ratified the Constitutional Treaty that had as its goal the salvaging of the substantial elements of the Constitution. This meeting was held before Sarkozy's victory and under German presidency, the same one that called the Intergovernmental Conference that gave birth to the Lisbon Treaty, signed in this capital city I3 December 2007.

For all these reasons, it can be said that Spain through its governments and through conventions, played a central role both in the Convention and in passing the Constitution as well as in saving it through the Treaty of Lisbon, supremely important Treaty in force since I December 2009, which Dr. Jose Maria Gil-Robles calls "Constitution without a name," since it salvages substantial elements of the European Constitution.

It is often repeated with great inaccuracy (there is even a book by that name) that in the European Union there exists a democratic deficit. However, there is a paradox in that Spain which could not preside at the birth of the Community due to its lack of democracy, has contributed to the disappearance of the famous deficit in a really significant way, being at the forefront of states that have helped to eliminate it with four constitutional reforms (Maastricht, Amsterdam, Nice, and Lisbon).

The expression "democratic deficit" was popularized by Artiero Spinelli in the r980s in the European Parliament to mean that a state that had the characteristics of a political system of the European Community would not form part of it because of being antidemocratic, since at that time the European Parliament did not have the instruments to control the executive and did not draft laws, which, needless to mention, has changed completely.

\section{SPAIN BEING A LOYAL AND EFFECTIVE PARTNER AT THE CORE OF THE EUROPEAN UNION} AND THE FOREFRONT OF THE POLITICAL UNION

The Spanish government of Felipe Gonzalez played an outstanding role in German reunification, which it supported when a great number of other heads of state were in opposition, among them the Prime Minister of Britain and the President of the French Republic, who would not accept it. The role of the catalyst in that decision was played by the President of the European Parliament at that time (Enrique Barón) and with it Spain positioned itself in a good place with respect to the FrenchGerman axis, of which it became part and to which it was always close (except for the period of the second popular government when it drifted toward the United Kingdom).

The participation of the Spanish government in the reform of the Treaties was very active: in Maastricht, with an important impulse, as well as in Amsterdam and in Nice (in this last case the government was more interested in the process of taking decisions, although also in the aspects of security and justice). This participation was especially relevant - as has been pointed out earlier- in the constitutional process and the salvaging of the Constitutional Treaty in the form of the Lisbon Treaty, and the only occasion that Spain was not together with the "more Europe" group was in December 2003, at the Council Of Rome, aligning with Poland's position and in a certain way with Italy and the United Kingdom, which led to a non-passing of the Treaty at that Council. 
Spain played a central role in the development and enforcement of the common policies (agricultural policy and policy of cohesion, among others) and carried out effectively its four presidencies of the European Council: in the first semester of 1989, in the second semester of 1995, in the first semester of 2002, and in the first semester of 2010.

Spanish commissioners Marcelino Oreja, Abel Matutes, Pedro Solbes, Loyola de Palacio, Joaquin Almunia and currently Arias Cañete have efficiently fulfilled their mission, being also outstanding the role of the three presidents of the European Parliament - Enrique Baron, Jose Maria Gil Robles and Josep Borrell- as well as the President of the Court of Justice, Gil Carlos Rodriguez Iglesias and the High Representative for Foreign Policy, Javier Solana, in addition to many other parliamentarians, politicians, senior officials, diplomats, etc., who were soon being called "Germans of the South" due to their efficiency and capacity for work.

Spain is at the core of the European Union by virtue of being one of the II founders of the Economic and Monetary Union, being part of the Schengen Agreement, having been involved in all the reforms of the treaties with the states that defended the deepening of Europe building and having supported enlargement processes, even the most problematic one, going from 15 to 25,27 , and 28 members.

Spain, being a loyal partner, has contributed leadership to the institutions (in various posts mentioned among others), which has reaffirmed its presence at the core of European construction, generally together with the Franco-German axis, achieving recognition similar to that of the founding countries. This position has reflected the federal European aspirations of the whole of Spanish society.

\section{THE STRENGTHENING OF THE INTERNATIONAL DIMENSION OF THE EUROPEAN UNION}

It has already been mentioned that Spain has contributed to Europe's international presence several centuries of presence in Latin America, the Mediterranean, and even Africa and Oceania. But above all, nowadays, Spain is part of global vision that it shares with the rest of the Europeans, and which at some moments we have championed.

Spain and important Spaniards have strengthened European foreign policy. With Javier Solana as the High Representative for Foreign Policy, the well-known Security Strategy was passed in December 2003, which is still in force. As its title states - "A Secure Europe in a Better World" - it is the most complete and innovative statement about European foreign policy since it says that Europe will be more secure if the world transforms. From this perspective development policy turns into a means to confront threats.

We do not generally recognize the notion of normative power, developed by Danish professor Jean Manners, referring particularly to the European Union's capacity to influence global governance through the development of norms and regulating it, as well as the importance of the Union as a diplomatic actor. However, we should keep in mind that in practice there has been a great number of Spanish proposals that have worked toward configuring this normative power. By way of example, among many others, is the creation of the International Criminal Court, proposal for climate change, moratorium on death penalty, the statute of the European Union in the General Assembly (equivalent 
to a state since 20I2), the Millennium Summit, and the Alliance of Civilizations all have an important Spanish component.

However, one cannot forget the Spanish error of supporting preventive intervention that implied the invasion of Iraq in 2003, contrary to international law, contrary to majority European opinion and with negative consequences for peace, with the aggravating circumstance that Spain was at the time part of the Security Council.

One should also remember that the decision adopted by the Council regarding the creation and functioning of the European External Action Service was made under Spanish Presidency, and that Spain has played a fundamental role in the design and launch of European common diplomacy, with an important contribution of diplomatic personnel and heads of missions. A Spaniard, Pedro Antonio Serrano de Haro, has just been named vice-secretary general within the European External Action Service, in charge of Common Security and Defence Policy (CSDP) and Crisis Response.

Finally, reference should be made to our participation in the resolution of the problem of dependence on third countries for security and defence through our drive toward Common Security and Defence Policy, an indispensable factor for Europe to be not only an international actor, but a leader in global politics. Currently another Spanish diplomat, Jorge Domecq, is at the forefront of the reform and deepening of the European Defence Agency. We have formed part of all the proposals that defend the launch, as soon as possible, of the Permanent Structured Cooperation (article 42.7 of the European Union Treaty), with a view to making the European Defensive Alliance credible, an urgency of the matter made all the more obvious by the progressive deterioration of security in Europe and not only in Spain.

\section{FACTORS THAT MAKE SPAIN'S CONTRIBUTIONS POSSIBLE}

This change, from not being able to participate in the building of Europe for political reasons, to being at the controls in a short period of time, contributing to the development of political Europe is due to at least five factors. What factors made this contribution possible?

a) That Spain's participation in Europe was a collective desire, with historical roots several centuries old. Although stifled in the 40 years of dictatorship, there was generated in civil society a progressive desire for incorporation during those difficult years.

b) That the European federal model toward which we are moving and which we have promoted as a state and society suits Spain as a medium/large power, while the three big ones need less supranational structure and feel comfortable in the intergovernmental structure, especially the British.

c) That in the beginning all the political and social forces around this project were in complete agreement with it, although at times this agreement was implicit. As already mentioned, the Treaty of Accession was the only treaty approved without a single vote against, there being a great consensus in the public opinion about this project (something not happening currently).

d) That the European project has been identified with the Spanish project, translating European values of democracy, equality, and solidarity to our language, and also, in the opposite direction, 
developing our values in the European key, in the form of such initiatives as citizenship and cohesion, even in common policies.

e) That, as we have seen before, Spaniards have not only been at the controls, but also in the engine room, forming part of the European civil service and through Spanish administration, both at the central level and that of autonomous communities, where a very effective management of common policies was achieved.

The Spanish contribution was also made possible by the Europeans' open reception and the fact that they always had Spain in mind as forming part of the project as well as a great number of politically or economically exiled Spaniards that participated in the European construction since its beginnings (as is the case of Eneko Landaburu, who worked in different directorates-general of the Commission, very close to Jacques Delors).

\section{OUR POLITICAL CONTRIBUTION BENEFITS SPAIN AND THE SPANISH PEOPLE}

Spanish political contribution to the European Union, apart from being a great input into the European construction, has benefited Spain and the Spanish people, with whose values and interests it coincided, especially in such aspects as consolidation of democracy in Spain, economic prosperity (when we joined we were at $70 \%$ of average European income per capita and today we are above average, despite the years of crisis and the statistical effects of the enlargement countries), and promotion of equality among regions, social classes and even generations through such policies as that of the environment or the reduction of public debt.

It is important to point out that the change from the economic nature of the European Community to the political nature of the European Union manifests itself mainly through more democracy, more efficiency, greater global presence, and more solidarity. And in this transformation, through the four above-mentioned factors, Spain has played a central role, which has benefited Spain and the Spanish people, as well as the rest of the Europeans.

In this sense, we can cite our promotion of democracy in the European Union, through the support of changes to the treaties that were moving in this direction, apart from contributions of our own such as the creation of citizenship. In addition to benefiting all Europeans, it heled to consolidate Spanish democracy. We must not forget that we experienced an attempted coup d'état as late as 198I, something that would be unthinkable now.

The same can be said in relation to the contributions regarding European efficiency and the improvement in decision-making processes, which have also influenced the development of our central and autonomous administrations, much more efficient today than in the beginning, in large part through the contagion of good practices of the Community model.

Spain, as an international actor, has attained an unprecedented role thanks to being part of the European Union, achieving something that would have seemed a fantasy thirty years ago, such as being part of the G-20 (even though Spain has a status of a permanent guest), at the moment in which participation in this type of forums is more difficult since they are open not just to Western countries. We should not forget that in 2008 Spain occupied the seventh place in global rankings 
(today, hopefully not for long we are in the fourteenth). We have already mentioned our participation in the development of the Community foreign policy model, which has impacted the development of our foreign policy.

Perhaps the clearest example of that is one related to solidarity, since it was precisely the Spanish proposal for the creation of economic and social cohesion in the Treaty of Maastricht that would favour the development of the whole of Community funds, especially the Cohesion Fund, achieving an operation of solidarity and transfer of funds that for some has been the largest in history, with Spain being by far the greatest beneficiary, obtaining almost I\% of gross domestic product from it during this period.

\section{OUR CONTRIBUTION COMMITS US TO THE CULMINATION OF THE HISTORIC PROJECT OF}

\section{FEDERAL REACH}

At this point, we should imagine the kind of Europe we are moving toward in the upcoming years, and what Spain can contribute to this project. The collective experience we have analyzed in the previous pages must serve as a guide and a commitment for establishing the collective strategy of the future, repeating the four structural elements that allow for the continuation of participation in this historic process: a) keeping in mind the above-mentioned European and Spanish advances, b) continuing developing the European project with a view to Spanish interests and values, c) developing it through the participation and great consensus of political and social forces, and d) defending the European federal model and reforming the Spanish Constitution in a federalist way, since they are both sides of the same coin. When the Spanish Constitution of 1978 was being drafted, we had in mind the accession to the European Community. Today, we have to be conscious in its reform of the federalist advance in the European Union.

On the other hand, we need to begin to expressly reject the notion of the "other Europe," since it ignores that it is precisely Europe that contributes to world history the model of welfare society, which is perhaps one of its greatest legacies, together with the defence of human rights.

It is understood that Juncker's program "A new beginning for Europe," passed by $60 \%$ of the European Parliament and supported by the Popular, Socialist, and Liberal groups contains adequate responses for the current legislature. The document titled "Realising the economic and monetary union" proposed by Juncker and supported by the four Presidents, foresees the necessary changes for the next decade, with the right economic vision, but insufficient politically, in my opinion. I believe that the Verhofstadt Report of the European Parliament together with that by Elmar Brok and Mercedes Bresso (still in the draft stage) are a good guide for the future.

Moreover the necessity of a Third European Convention must be defended once the economic crisis has been overcome (perhaps for 2018, since it will be 70 years since the Congress of the Hague, having finished one year before the five year term set for "communitising" the Treaty of Economic Coordination for twenty-six members). The goal of this third convention will be the reform of the treaties in the direction of developing their political model, armour plating the above-mentioned welfare society (which has been shaken but not destroyed in the last six years), extending the 
economic, financial, and budgetary union and social union, as well as cohesion and advances in the matters of foreign policy and defence.

In any case, what is lacking in this group of documents is Spanish vision of political Europe, following the trajectory that we have signalled in this study, since only the economic one has been reflected until now. I will cite some examples of the elements to have in mind for the design of this political Europe:

a) Recover and update the notion of economic cohesion with the goal of solving one of Spain's structural problems - unemployment (in which we are leaders, with almost triple the European average) - through one of the instruments equivalent to the cohesion funds or regional funds targeted at solving the problem of unemployment.

b) Develop the notion of citizenship, of participative democracy, and improvement of representative democracy through the role of the European Parliament in ordinary legislative procedure.

c) Strengthen the Mediterranean Group within the European Union, giving continuity to the Alicante and Barcelona meetings with foreign ministers of southern countries. It is about strengthening the Mediterranean flank in the face of northern countries.

d) Take leadership of Euro-Latin American cooperation, promoting, for example, Euro-Latin American Space for Higher Education.

We have to keep in mind that as a consequence of enlargements that the European Union has undertaken eastward Spain is every time left more on the periphery, which demands that we rethink our strategy to compensate for this situation and do the following:

a) Develop the constitutional model through the aforementioned European Convention.

b) Defend the European Union as a global power, confirming and maintaining Solana's foreign policy strategy.

c) Understand that the exit of the United Kingdom or Greece would hurt us, since in the first case it would leave us practically alone in the Atlantic and in the case of Greece, it is a country that has to support cohesion in the matter of employment which we have just mentioned.

d) Present a strong program with Latin America that would promote free trade and even an agreement not only with the United States (which is necessary), especially through the development of Euro-Latin American space.

e) Develop Common Security and Defense Policy, beginning with the putting into motion of the Permanent Structured Cooperation, accepted by everyone but which has a special relevance for us, since risks and threats have increased, and yet we are reducing the Defence Budget.

\section{CONCLUSION: EUROPE IS A PATH, NOT A FINAL DESTINATION}

My perspective, which is reflected in these lines, has tried to discover the values, interests, and vision of the world which we have defended during these thirty years and which project into the future. With that we try to give continuity to the historical project, knowing that "Europe is the path, not a final destination," in the words of Jose Ortega and Gasset, and that the fundamental contribution that Spaniards have made consists in collaborating toward strengthening, deepening, and transforming of 
the economic community into a political union with federal reach, thanks to emphasizing our historical roots, our political consensus, being a loyal and effective partner, participating at the core and identifying the European political project with the Spanish one.

A lot of things have changed in the world in thirty years. Spain has changed, and the European Community has transformed into the European Union, having to confront what Luuk Van Middlar calls "a step toward Europe," which means, no more and no less, going from "we, the states" to "we, the citizens," overcoming the current situation, which is "we the states and the citizens." To do that, the key will be in finding a formula which will make it possible to change the treaties without the need for unanimity of the member states, maybe a supermajority.

The economic and self-confidence crisis of the Europeans has to be overcome through the reflection on and evaluation of the work done, especially the change in the nature of the Union, from economic to political union, with the goal of completing it and putting the roof on the building, as formulated by Leo Tindemans. We, Spaniards, have to design a European strategy which would include, as until now, our values, interests, and vision of the world.

This obliges us to continue in the design of the future model, keeping in mind our aforementioned contribution. For this we must remain at the controls, and not just in the engine room, which requires, remembering the master federalist professor Dusan Sidjanski, that we be conscious of the fact that we form part of the builders, that we are constructing - and not just placing bricks - the cathedral of the European Federation, the first construction in the history of humanity that has united states and citizens without using force, solely through justice and democratic means that have made possible for the first time to share political sovereignty.

In 1948, Spaniards participated in the Congress of The Hague, in which the European Movement was created, the promoter of this entire process of Europe building. From its beginnings until Spain's joining the European Community, the Spanish Federal Council of the European Movement played a central role in representing society in achieving this objective, it being fair to highlight the work of many of its presidents, among them Fernando Alvarez de Miranda. The work of the Basque and Catalan councils must also be mentioned.

During the thirty years that have passed since our joining the European Community, in Spain the federalist torch has continued to burn bright through the Federal Council, which has always been at the vanguard of Spanish society in the deepening toward more Europe. We should remember that Enrique Baron and Jose Maria Gil-Robles were presidents of the International European Movement, playing a great role. We should also remember the efforts of many people who participated in the Federal Council. I want to mention especially the last presidents, Carlos Bru and Eugenio Nasarre who have revitalized the Movement during the last four years, tying it to the re-launch that is currently happening in all of the member countries. 